\title{
Methodical bases of the proposal evaluation of investment resources in the construction industry
}

\section{Yurii Chirichenko}

Dr., Professor, the Department of International Economic Relations and Management, University of Finance, Ukraine

\section{Nadia Fisunenko}

$\mathrm{PhD}$ student, the Department of International Economic Relations and Management, University of Finance, Ukraine

\begin{abstract}
In this article, the indicators characterizing the supply of investment resources in construction are substantiated. The direction of their influence on the effective index is determined. In parallel, in addition to the relevant indicators of the characteristics of the offer of investment resources in construction, the information base of the model should take into account the factors that influence and adjust the functions of the proposal, namely, the index of investment attractiveness; index of financial freedom; index of freedom of investment; inflation index; official exchange rate of hryvnia to US dollar; the general tax burden on business. The existing information base of the study allowed to develop a scientific and methodical approach to formalizing the functions of the offer of investment resources in construction, which includes the following stages: 1) bringing the input mass of statistical data and corrective indicators to the co-ordinated form (some methods of normalization are proposed for indicators of stimuli and indicators of disintegration); 2) calculation of the integral indicator of the supply of investment resources in construction through the adaptation of the metric of Minkowski; 3) formalization of the functions of offering investment resources in construction as multiplicative distributive-lag multifactorial nonlinear regression dependencies.
\end{abstract}

Keywords: offer, integral indicator, relevant factors, investment resources, construction industry. JEL Classification: G00, G11.

(C) The Authors, 2018. This article is published with open access at Sumy State University.

\section{Introduction}

Contemporary development of any branch of the economy is impossible without attracting investment resources. The construction industry is no exception. Investment resources not only allow expanding the volume of constructed objects, but also carry out qualitative change and modernization of production facilities and building materials. Innovative developments, which under present conditions of economic activity are the main competitive advantage, are impossible without investments.

Considering this problem in the context of the state, it is fair to note that the globalization of all economic processes and the internationalization of borders have led to the need to defend the national interests of domestic business entities. Despite the fact that in the construction industry, most of them are domestic companies, but foreign consortia that use the latest technologies are able to come to the domestic construction market and completely monopolize it both at the state and at the regional level. Thus, the study of internal sources of formation of investment resources, which can be directed to the construction industry and observance of the constant equilibrium between the quest and the offer on them, becomes relevant. This situation necessitates the development of mathematical tools that would enable to form an information base for the adoption of optimal managerial decisions regarding the intensity of the increase in the volume of the supply of investment resources in construction. This will lead to a synergistic effect for the national economy of Ukraine in the form of increased financial resources, which will be sent by economic agents to build and increase the share of construction in the country's GDP.

\section{Literature review and discussion}

Considering the research carried out in the article as a complex of three different areas of scientific knowledge, namely the formalization of the function of the proposal, the analysis of investment resources in various sectors of the economy and research of the construction industry, it is fair to note that the attention of the international scientific community was paid to each of the selected areas. So, most scholars consider different aspects, types of interactions, and the features of the supply function equilibria. 
In turn, Anderson E. J. and X. Hu. finding supply function equilibrium with asymmetric firms. In previous studies, Anderson E. J., but with A. B. Philpott studied the use of supply functions for generating generation into an electricity market. Holmberg P. Investigates the supply equilibrium with asymmetric capacities and constant marginal costs. Klemperer Paul D. and Margaret A. Meyer focused on identifying the supply equilibrium in oligopoly under uncertainty. Another way was to analyze the supply function equilibrium by such scientists as Sioshansi R., Oren S. They conducted an empirical analysis of the ERCOT balancing market, which allows us to determine the most efficient supply function equilibrium model. The research of CambraFierro J. and Polo-Redondo Y. is interesting in which they determine the causes, determinants and implications of the supply function. This study allows you to determine the vectors that are chosen to determine the relevant indicators of the desired function. Separately, studies devoted to the analysis of labor supply can be singled out, they are, in our opinion, the basis of any research on the supply function evaluation, since they determine the regularity of the behavior of this function and the factors that determine it. This subject was dealt with by Bargain O., Orsini K., A. Peichl, R. Blundell, C. Meghir C. and P. Neves.

Chege L., Duff D., Sader F. works highlight the problems associated with investing in construction products, opportunities and challenges of private investment in infrastructure, as well as the mechanism of attracting foreign direct investment into infra-structure.

Significant scientific work is also being followed in the study of processes in the construction industry. Modern trends in the development of construction industry under the influence of globalization have been investigated in a large group of scientists, namely Ofori G., Raftery J., Bernie P., Chiang Y.H., Eddie C.M.H and Tang S.B. An additional aspect of the study of construction industry by Ofori G. is the formalization of strategic planning for competitive advantage.

The detailed analysis of existing thoughts on the characteristics of the supply of investment resources, the mechanism for the formation of investment resources in the construction industry of the mathematical tool for assessing demand shows that all scholars agree on the need to objectively construct the function of demand for investment resources in any which branch of the economy. This allows, in the future, to determine the optimum equilibrium value of the supply of investment resources, knowing which government authorities will be able to apply effective investment policy instruments. Thus, the development of a model for evaluating the supply of investment resources in the construction industry, which will allow business entities and public authorities to actively influence the development of the construction industry, becomes actuality.

\section{Methods and Results}

Turning to the development of the author's methodology for forming the function of offering investment resources in construction in Ukraine, we note that the development of a relevant scientific methodological approach will include four phases, each of which will consist of several steps. Thus, the first stage of the scientific and methodical approach to the evaluation of the offer of investment re-surs in construction involves the formation of an input array of indicators of the characteristics of the desired function. Thus, it is proposed to select, as the relevant indicators of the function of offering investment resources in construction, to choose: saving of households; financial result before taxation of economic entities; working capital of economic entities; capital investments of business entities; capital investment from budgets; assets of insurance companies; assets of non-state pension funds; assets of credit unions; assets of banks; rate on long-term loans. In order to interpret the logic of selecting the above group of indicators, let us dwell on each of them in more detail. Thus, household savings are a potential indicator of the amount of available financial resources that can be transformed into investment in the construction industry. Savings of the population under favorable conditions on the real estate market and parallel insufficient profitability of other financial assets, as well as high currency risks, can form a significant supply of investment resources in construction.

The following three indicators, namely, the financial result before taxation of business entities, working capital of economic entities and capital investments of business entities, describe the potential investment resources that are at the disposal of enterprises and provided the favorable economic situation in the state, as well as a transparent domestic investment market, will be sent to the construction industry of Ukraine. Thus, the financial result before taxation of economic entities characterizes the amount of undistributed profits of enterprises of Ukraine, which, based on the decision of shareholders or management institutions, can be directed to the construction of infrastructure of the production process. Capital 
investment from the budgets of all levels, as well as population savings and capital investments of economic entities, reflect the existing investment potential that can be realized in the construction industry, but by the state. Assets of such financial intermediaries as insurance companies, non-state pension funds, credit unions and banks are also indicators of financial resources that can be directed in the form of investment in construction, but in each case, the share of such assets will be different, based on from state norms, which fix the share of assets that can be sent to the investigated industry.

Thus, according to the Law of Ukraine "On Insurance", insurers are able to direct to the objects of construction no more than $35 \%$ of their assets. The data of $35 \%$ consist of $20 \%$, which can be directed to investments in the Ukrainian economy, including long-term loans for residential construction, as well as $15 \%$ in mortgage certificates. For private pension funds investment activities regulated by the Law of Ukraine "On private pension provision", which stipulates that private pension funds have the right to direct more than $10 \%$ of its assets in real estate financing.

The Law of Ukraine "On credit unions" is not defined any limits on the investment of assets, so we believe that the full amount of financial resources at the disposal of the credit unions may be sent in the form of investment in construction. Individual approach is to establish the share of banks' assets, which can be interpreted as the potential financial resources that form the supply of investment resources in the construction industry. Thus, the author believes that among all the bank's assets, appropriate as investment resources that can be directed to the construction and to choose the fate of long-term loans. This is due to the fact that this type of loans can be used to finance the purchase of real estate (the process of refunding the funds spent on the acquisition of real estate for a long time considering the high cost of the property) or their construction (the construction process lasts more than one year). We consider all other assets of the bank to be inappropriate as potential financial resources that can form a supply of investment resources in construction, since they can not be practically used in this direction. In the last relevant indicator of the characteristics of the supply of investment resources in the building is the rate on long-term loans. In our opinion, this indicator should be chosen not as a characteristic of the available financial resources that make up the supply of investment resources in construction, but as an indicator of the price of these resources. Information base of ten values is higher than indicators for 2000-2017. It is presented in Table 1 (see in Appendix).

It is also relevant to determine the direction of influence of the analyzed factor factors on the resultant. The household savings; financial result before taxation of business entities; working capital of economic entities; capital investments of subjects of state-domination; capital investment from budgets; assets of insurance companies; assets of non-state pension funds; assets of credit unions. The assets of banks are indicators of stimulants, that is, their increase leads to an increase in the supply of investment resources in construction. In turn, the rate on long-term loans is an indicator of a disintegrator, since its growth reduces the financial resources that can be transformed into investment in construction.

In describing the information base, we have repeatedly focused on the fact that the available financial resources from households, enterprises, financial intermediaries and the state are transformed into investment resources in the construction industry only under favorable conditions in the Ukrainian economy as a whole and the investment market in particular. Proceeding from this, the process of adjusting the function of offering investment resources in construction on an appropriate coefficient becomes relevant. Thus, this corrective factor should accumulate indicators of the characteristics of the level of conductivity of investment and economic activity in Ukraine. Thus, the author proposed as indicators that will shape the coefficient of co-regulation of the function of proposals for investment resources in the construction to choose: the index of investment attractiveness; index of financial freedom; index of freedom of investment; inflation index (consumer price index); official exchange rate of hryvnia to US dollar; the total tax burden on business.

Turning to each indicator separately, we note that the index of investment attractiveness is chosen by us because of its complexity, and the characteristics of macro and microeconomic conditions of the functioning of the state's economy. That is, the numerical value of this index provides information on the general conditions for the functioning of economic agents in the country and, accordingly, their ability to carry out investment activities. This factor is a stimulant. That is, its growth will increase the correction factor.

The index of financial freedom is a component of the index of economic freedom, however, the election of it itself, and not of the index of economic freedom, is due to the fact that the indicator already incorporates 
an indicator describing general economic processes. In turn, when choosing the second indicator of the characteristic of the adjustment of the offer function, the actuality of the activity, which describes purely financial conditions of conducting business in Ukraine, becomes relevant. This is due to the fact that the freedom of financial activity creates an impulse for the constant increase of investment resources, which can be directed to any sphere, including construction. This factor is a stimulant.

Thus, the above three indicators of the characteristics of the correction factor of the offer of investment resources in construction are described, describe the situation in a state that activates or vice versa slows down investment activity by the population, economic entities and the state itself.

The following three indicators describe a separate process, however, which has a synergistic effect on all economic agents who wish to invest their own funds in construction. Thus, the inflation index is the first indicator, the increase of which leads to a significant reduction of investment resources. So, under the condition of active inflation processes in the state, financial resources, which potentials can be directed as investments in construction, are not only depreciated, but also the price of investment assets increases.

The UAH rate to the US dollar is probably the most destructive factor in terms of investment activity, since in Ukraine the value of real estate, construction materials and construction materials is "tied" to the US dollar. That is, an increase in the hryvnia to the US dollar will inadvertently reduce the growth of the supply of investment resources in construction and inflate the free financial resources into physical storage in foreign currency. Instead of the indicator "general tax burden on business", it was possible to choose the index of tax freedom, however, in our opinion, it is the proportion of the state's withdrawal of circulating and capitalized funds of economic entities reduces the volume of potential investment resources. The number of taxes, the mechanism of their administration, control, etc., included in the tax freedom index is important for the overall efficiency of business entities, but also indirectly affects the amount of free financial resources at enterprises. Thus, in the framework of this study, the emphasis is on the indicator the total tax burden on business.

All three indicators, which are de-stimulators and their increase, will lead to a decrease in the supply of investment resources in construction. The formation of the input characteristic of the dynamics of the correction indicators is presented in Table 2 (see in Appendix).

Summing up this step of the first stage of the proposed scientific and methodological approach, we note that the coefficient of correction of the function of the offer of investment resources in construction, as well as its components, can take values and more than one. This suggests that economic agents can increase investment resources in the construction of Ukraine. At the same time, it is fair to note that this increase can only take place under conditions of successful development of the national economy, namely, improvement of the investment climate in Ukraine, increase of GDP growth, stabilization of the currency market, neutralization of corruption in legislative, executive and judicial branches of power, liberalization of tax legislation and reduction of tax pressure on enterprises and households.

Thus, at the first stage of the implementation of the proposed scientific methodological approach to evaluation, the formation of the input mass of the statistical information necessary for the economic-mathemati$\mathrm{cal}$ formalization of the function of the offer of investment resources in construction was made. Thus, each relevant indicator of the estimation of the investment supply function function in the construction is substantiated and the direction of their influence is identified.

Turning to the second stage of the implementation of the scientific and methodological approach to the evaluation of the supply of investment resources in construction, we note that its essence is to bring all input indicators to a comparable view. The importance of this stage is that the quantitative representation of the function of the offer of investment resources in construction is possible only at the expense of mathematical transformations of the same measure indicators. Consequently, the practical realization of this stage involves the preliminary normalization of input indicators using the following formulas.

So, for indicators of stimulants, in our case it is: saving of households; financial result before taxation of business entities; working capital of economic entities; capital investments of business entities; capital investment from budgets; assets of insurance companies; assets of non-state pension funds; assets of credit unions; the assets of banks, the formula for normalization will take the following form: 


$$
\widetilde{x_{\imath J S}}=\left|1-\frac{x_{i j s}}{x_{\operatorname{maxjs}}}\right|
$$

where $\widetilde{x_{\imath j S}}$ - the normalized value of the $j$ indicator of the characteristics of the supply of investment resources in the boulevard for the $i$ year;

$x_{i j s}$ - input absolute value of the $j$ indicator of the characteristics of the supply of investment resources in construction for the $i$ year;

$x_{\operatorname{maxjs}}$ - the maximum possible value of the $j$ index of the characteristics of the offer of investment resources in the construction for the time range considered;

For indicators-disintegrants, in our case, this is the only indicator - the rate for long-term loans, the formula for normalization will have the form:

$$
\overline{x_{l S 10}}=\left|1-\frac{x_{\operatorname{minS10}}}{x_{i S 10}}\right|
$$

where $\overline{x_{l S 10}}$ - normalized value of the rate on long-term loans for the $i$ year;

$x_{\operatorname{minS} 10^{-}}$the minimum possible value of the rate for long-term loans for the considered time-diagonal;

$x_{i S 10}$ - the input absolute value of the rate for long-term loans for the $i$ year;

Results of practical calculation on the basis of formulas 1 and 2 of the values of the input mass of information are grouped in Table 3.

\begin{tabular}{|c|c|c|c|c|c|c|c|c|c|c|}
\hline \multirow{2}{*}{ 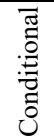 } & \multirow[b]{2}{*}{ Indicator } & \multicolumn{9}{|c|}{ Year } \\
\hline & & 2000 & 2001 & 2002 & 2003 & 2004 & 2005 & 2006 & 2007 & 2008 \\
\hline S1 & Savings, UAH million & 0.975 & 0.128 & 1.000 & 0.179 & 0.259 & 0.338 & 0.330 & 0.349 & 0.372 \\
\hline S2 & $\begin{array}{l}\text { Financial result before tax } \\
\text { (profit / loss), UAH million }\end{array}$ & 0.952 & 0.678 & 0.681 & 0.688 & 0.717 & 0.725 & 0.739 & 0.781 & 0.656 \\
\hline S3 & Working capital, mln.UAH & 0.950 & 0.010 & 0.021 & 0.034 & 0.050 & 0.068 & 0.090 & 0.116 & 0.146 \\
\hline S4 & $\begin{array}{l}\text { Capital investment from enter- } \\
\text { prises, mln.UAH }\end{array}$ & 0.944 & 0.011 & 0.024 & 0.047 & 0.100 & 0.123 & 0.188 & 0.304 & 0.392 \\
\hline S5 & $\begin{array}{l}\text { Capital investment from budg- } \\
\text { ets of all levels, mln }\end{array}$ & 0.961 & 0.008 & 0.019 & 0.063 & 0.170 & 0.124 & 0.185 & 0.285 & 0.353 \\
\hline S6 & $\begin{array}{l}\text { Assets of insurers, UAH mil- } \\
\text { lion }\end{array}$ & 0.961 & 0.008 & 0.051 & 0.152 & 0.333 & 0.222 & 0.332 & 0.371 & 0.469 \\
\hline S7 & Assets of NPF, UAH million & 0.996 & 0.001 & 0.003 & 0.006 & 0.010 & 0.015 & 0.052 & 0.111 & 0.245 \\
\hline S8 & $\begin{array}{l}\text { Assets of credit unions, UAH } \\
\text { million }\end{array}$ & 0.901 & 0.009 & 0.018 & 0.028 & 0.050 & 0.245 & 0.483 & 0.853 & 1.000 \\
\hline S9 & Assets of banks, UAH mln. & 0.970 & 0.009 & 0.022 & 0.047 & 0.074 & 0.136 & 0.235 & 0.438 & 0.694 \\
\hline S10 & Rate on long-term loans, $\%$ & 0.444 & 0.424 & 0.404 & 0.383 & 0.361 & 0.339 & 0.320 & 0.311 & 0.332 \\
\hline
\end{tabular}

Table 3. The characteristics of the indicators of investment resources in construction (2000-2008)

\begin{tabular}{|c|c|c|c|c|c|c|c|c|c|c|}
\hline $\bar{\Xi}$ & \multirow[b]{2}{*}{ Indicator } & \multicolumn{9}{|c|}{ Year } \\
\hline $\begin{array}{l}0 \\
0 \\
0\end{array}$ & & 2009 & 2010 & 2011 & 2012 & 2013 & 2014 & 2015 & 2016 & 2017 \\
\hline S1 & Savings, UAH million & 0.526 & 0.921 & 0.757 & 0.888 & 0.720 & 0.258 & 0.259 & 0.159 & 0.000 \\
\hline S2 & $\begin{array}{l}\text { Financial result before tax } \\
\text { (profit / loss), UAH million }\end{array}$ & 0.590 & 0.717 & 0.796 & 0.771 & 0.681 & 0.000 & 0.226 & 0.618 & 1.000 \\
\hline S3 & Working capital, mln.UAH & 0.218 & 0.253 & 0.319 & 0.357 & 0.427 & 0.402 & 0.468 & 0.622 & 1.000 \\
\hline S4 & $\begin{array}{l}\text { Capital investment from enter- } \\
\text { prises, mln.UAH }\end{array}$ & 0.269 & 0.321 & 0.445 & 0.525 & 0.507 & 0.469 & 0.570 & 0.791 & 1.000 \\
\hline S5 & $\begin{array}{l}\text { Capital investment from budg- } \\
\text { ets of all levels, mln }\end{array}$ & 0.158 & 0.252 & 0.419 & 0.414 & 0.197 & 0.118 & 0.347 & 0.620 & 1.000 \\
\hline S6 & $\begin{array}{l}\text { Assets of insurers, UAH mil- } \\
\text { lion }\end{array}$ & 0.464 & 0.550 & 0.570 & 1.000 & 0.767 & 0.823 & 0.735 & 0.707 & 0.728 \\
\hline S7 & Assets of NPF, UAH million & 0.345 & 0.462 & 0.560 & 0.671 & 0.846 & 1.000 & 0.801 & 0.866 & 0.999 \\
\hline S8 & $\begin{array}{l}\text { Assets of credit unions, UAH } \\
\text { million }\end{array}$ & 0.662 & 0.518 & 0.327 & 0.377 & 0.366 & 0.318 & 0.268 & 0.262 & 0.288 \\
\hline S9 & Assets of banks, UAH mln. & 0.653 & 0.707 & 0.794 & 0.852 & 0.969 & 1.000 & 0.950 & 0.958 & 0.973 \\
\hline S10 & Rate on long-term loans, $\%$ & 0.431 & 0.181 & 0.142 & 0.220 & 0.166 & 0.245 & 0.262 & 0.145 & 0.000 \\
\hline
\end{tabular}

Table 3 (cont.). The characteristics of the indicators of investment resources in construction (2009-2012) 
Selection of formulas 1 and 2 to normalize the input array of statistics is due, firstly, that the input supply evaluation of investment resources in the construction of Ukraine for 2000-2017 years. Become as positive and negative values, and secondly, that it is necessary to get the normalized values in the interval from zero to one.

The implementation of the second step of the second stage is proposed to be carried out according to the following formulas. For corrective indicators-stimulants (index of investment attractiveness, index of financial freedom, index of freedom of investment):

$$
K_{i l}=\frac{k_{i l}}{1 / m \sum_{l=1}^{m} k_{i l}}
$$

where $K_{i l}$ - the normalized value of the indicator for adjusting the supply of investment resources in construction for the $i$ - year;

$k_{i l}$ - the input absolute value of the 1st indicator of the adjustment of the supply of investment resources in the budget for the $i$ - year

For corrective indicators of disinfestation (inflation index (consumer price index); official exchange rate of UAH to US dollar; general tax burden on business):

$$
K_{i l}=\frac{1 / m \sum_{l=1}^{m} k_{i l}}{k_{i l}}
$$

The results of the practical calculation on the basis of formulas 3 and 4 of the normalized values of the correction coefficients of the supply of investment resources in construction are grouped in Table 4.

\begin{tabular}{|c|c|c|c|c|c|c|c|c|c|c|c|c|c|c|c|c|c|c|c|}
\hline \multirow[b]{2}{*}{ № } & \multirow[b]{2}{*}{ Indicator } & \multicolumn{18}{|c|}{ Year } \\
\hline & & ¿ి & ఠ్ & ণิ & ڤి & ণ্ণ & 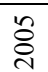 & ¿্ণ & ¿े & 㝘 & ठ্े & $\stackrel{\circ}{\stackrel{\circ}{\circ}}$ & $\overrightarrow{\bar{\sigma}}$ & $\stackrel{\sim}{\stackrel{\sim}{\sim}}$ & $\stackrel{m}{\stackrel{n}{s}}$ & $\stackrel{\nabla}{\stackrel{\sim}{\sigma}}$ & $\stackrel{n}{\stackrel{\sim}{*}}$ & $\stackrel{0}{\stackrel{\circ}{\circ}}$ & $\stackrel{ }{\vec{\Omega}}$ \\
\hline 1 & $\begin{array}{l}\text { Investment } \\
\text { attractiveness index, } \\
\text { unit. }\end{array}$ & - & - & - & - & - & - & - & - & - & 2.5 & 3.2 & 2.9 & 2.2 & 2.1 & 2.7 & 2.6 & 2.9 & 3.1 \\
\hline 2 & $\begin{array}{l}\text { Index of Financial } \\
\text { Freedom, units }\end{array}$ & 1.0 & 1.0 & 1.0 & 1.0 & 1.0 & 1.0 & 1.0 & 1.0 & 1.0 & 0.9 & 1.2 & 1.1 & 0.8 & 0.8 & 1.0 & 1.0 & 1.1 & 1.2 \\
\hline 3 & $\begin{array}{l}\text { Index of freedom of } \\
\text { investment, units }\end{array}$ & 0.8 & 0.8 & 0.8 & 1.3 & 1.3 & 1.3 & 1.3 & 1.3 & 1.3 & 1.1 & 0.8 & 0.8 & 0.8 & 0.8 & 0.8 & 0.8 & 0.8 & 0.8 \\
\hline 4 & $\begin{array}{l}\text { Inflation Index } \\
\text { (Consumer Price In- } \\
\text { dex),\% }\end{array}$ & 1.7 & 1.7 & 1.7 & 1.0 & 1.0 & 1.0 & 1.0 & 1.0 & 1.0 & 1.0 & 0.7 & 0.7 & 0.7 & 0.7 & 0.7 & 0.5 & 0.7 & 0.9 \\
\hline 5 & $\begin{array}{l}\text { Official exchange } \\
\text { rate of UAH to US } \\
\text { dollar }\end{array}$ & 0.9 & 1.0 & 1.1 & 1.1 & 1.0 & 1.0 & 1.0 & 1.0 & 0.9 & 1.0 & 1.0 & 1.1 & 1.1 & 1.1 & 0.9 & 0.8 & 1.0 & 1.0 \\
\hline 6 & $\begin{array}{l}\text { Total tax burden on } \\
\text { business, } \%\end{array}$ & 1.8 & 1.8 & 1.8 & 1.8 & 1.8 & 1.9 & 1.9 & 1.9 & 1.8 & 1.2 & 1.2 & 1.2 & 1.2 & 1.2 & 0.8 & 0.4 & 0.4 & 0.4 \\
\hline
\end{tabular}

Table 4. The values of indicators of adjustment of supply for investment resources in construction

The third stage of the implementation of the proposed scientific methodological approach is to calculate the indefinite indicator of the supply of investment resources in construction. It is advisable to make a practical solution to this problem by adapting the Minkowski metric by forming the function of utility as a separate case of this approach.

Considering the above formula normalization parameters, the desired integral index gain following:

$$
I\left(x_{i s}\right)=\sum_{j=1}^{k} w_{j} .\left|1-\frac{x_{i j s}}{x_{\text {maxjs }}}\right|+\sum_{j=k+1}^{n} w_{j} .\left|1-\frac{x_{\text {min } j s}}{x_{i j s}}\right|
$$

Where $I\left(x_{i s}\right)$ - integral indicator of the supply of investment resources in construction for the $i$ - year;

$w_{j s^{-}}-$weight factor (specific gravity) $\mathrm{j}$-th indicator of the characteristics of the offer of investment resourses in construction. In the next step of this stage, there is a need for adjusting the integral index, which will result in its formalization as follows: 


$$
I\left(x_{i s}\right)=\left(\sum_{j=1}^{k} w_{j .}\left|1-\frac{x_{i j s}}{x_{\text {maxjs }}}\right|+\sum_{j=k+1}^{n} w_{j .}\left|1-\frac{x_{\min j s}}{x_{i j s}}\right|\right) \cdot \prod_{l=1}^{L} K_{i l}
$$

At the same time, it should be noted that based on the fact that the adjustment of the supply of investment resources in construction requires taking into account different coefficients, in the general form, the nominated complex indicator of the adjustment of the proposal will take the form:

$$
\prod_{l=1}^{6} K_{i l}
$$

The results of calculations of formula 7 are given in Table 5 .

\begin{tabular}{|c|c|c|c|c|c|c|c|c|c|}
\hline \multirow[t]{2}{*}{ Indicator } & \multicolumn{9}{|c|}{ Year } \\
\hline & 2000 & 2001 & 2002 & 2003 & 2004 & 2005 & 2006 & 2007 & 2008 \\
\hline Offer & 1.20 & 1.22 & 1.25 & 1.21 & 1.21 & 1.20 & 1.21 & 1.20 & 1.18 \\
\hline
\end{tabular}

Table 5. Dynamics of indicators of adjustment for investment resources in construction (2000-2008)

\begin{tabular}{|c|c|c|c|c|c|c|c|c|c|}
\hline \multirow{2}{*}{ Indicator } & \multicolumn{9}{|c|}{ Year } \\
\hline & 2009 & 2010 & 2011 & 2012 & 2013 & 2014 & 2015 & 2016 & 2017 \\
\hline Offer & 1.03 & 0.99 & 0.96 & 0.94 & 0.94 & 0.87 & 0.76 & 0.83 & 0.94 \\
\hline
\end{tabular}

Table 5 (cont.). Dynamics of indicators of supply for investment resources in construction (2009-2017)

$$
S\left(x_{i}\right)=0.1 \cdot\left(\sum_{j=1}^{9}\left|1-\frac{x_{i j}}{x_{\max j}}\right|+\left|1-\frac{x_{\min 10}}{x_{i 10}}\right|\right) \cdot \prod_{l=1}^{6} K_{i l}
$$

where $S\left(x_{i}\right)$ - Adjusted integral indicator of estimation of supply of investment resources in construction for the $i$ year;

The absolute values of the integral indicators of the evaluation of the proposal for investment resources in construction (calculated by the formulas 8 ) are not economically interpretable, therefore, it is necessary to switch to relative values in the range from zero to one by the formula 9 , which involves weighing the absolute values of the integral indicator of the supply of investment resources in construction at the maximum possible level for the investigated time interval:

$$
I_{S\left(x_{i}\right)}=\frac{S\left(x_{i}\right)}{S\left(x_{i}\right)_{\operatorname{maxi}}}=\frac{0.1 \cdot\left(\sum_{j=1}^{9}\left|1-\frac{x_{i j}}{x_{\max j}}\right|+\left|1-\frac{x_{\min 10}}{x_{i 10}}\right|\right) \cdot \Pi_{l=1}^{6} K_{i l}}{\max _{i}\left\{0.1 \cdot\left(\sum_{j=1}^{9}\left|1-\frac{x_{i j}}{x_{\max }}\right|+\left|1-\frac{x_{\min 10}}{x_{i 10}}\right|\right) \cdot \prod_{l=1}^{6} K_{i l}\right\}}
$$

where $I_{S\left(x_{i}\right)}$ - the relative value of the integral indicator of the estimation of the supply of investment resources in construction for the $i$ - year, brought to the gap from zero to one;

$S\left(x_{i}\right)_{\text {maxi }}$ - the maximum possible relative value of the integral indicator for assessing the supply of investment resources in the construction of the investigated time range.

The results of calculations by formulas (8), (9) are given in Table 6.

Table 6. Dynamics of absolute and relative integral indicators of evaluation for investment resources in construction

\begin{tabular}{|c|c|c|c|c|c|c|c|c|c|}
\hline \multirow{2}{*}{ Indicator } & \multicolumn{9}{|c|}{ Year } \\
\hline & 2009 & 2010 & 2011 & 2012 & 2013 & 2014 & 2015 & 2016 & 2017 \\
\hline$S\left(x_{i}\right)$ & 0.447 & 0.482 & 0.495 & 0.569 & 0.529 & 0.404 & 0.369 & 0.477 & 0.655 \\
\hline$I_{S\left(x_{i}\right)}$ & 0.412 & 0.444 & 0.456 & 0.524 & 0.488 & 0.373 & 0.340 & 0.440 & 0.603 \\
\hline
\end{tabular}

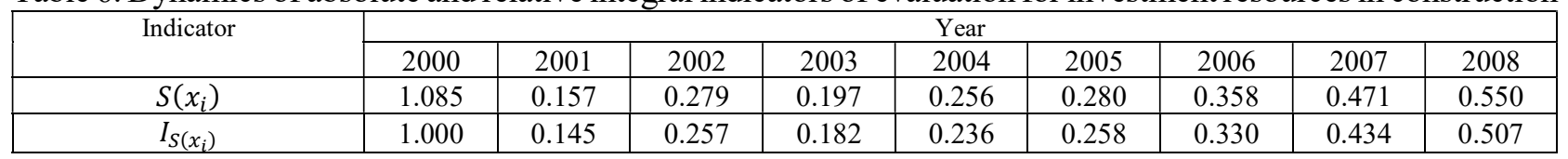

Table 6 (cont.). Dynamics of absolute and relative integral indicators of evaluation for investment resources in construction

At the final fourth stage of the implementation of the proposed scientific and methodological approach, it is necessary to form the functions of the proposal on investment resources in construction as multiplicative 
distributive-lag multifactorial nonlinear regression dependencies. The solution of which allows to receive the following function of the offer of investment resources in construction:

$$
\begin{array}{r}
S(t)=e^{-11.655-1.379 \cdot S 1(t-3)} \cdot S 2^{0.061}(t-3) \cdot S 3^{-2 \cdot 0.035}(t) \cdot S 4^{0.084}(t 3) \cdot S 5^{0.256}(t-1) \\
\cdot S 6^{0.008}(t-5) \cdot S 7^{-0.486}(t 3) \cdot S 8^{2 \cdot 0.065}(t-4) \cdot S 9^{1.025}(t) \cdot e^{-0.043 \cdot S 10}(t)
\end{array}
$$

Thus, the analytical formalization of the function of the offer of investment resources in Ukraine has been carried out, which makes it possible to determine the predictive values of this effective indicator, depending on the ten factor factors. In addition, it is fair to note that the formed function takes into account the different temporal effects of each factor.

\section{Conclusions}

The conducted study allowed to establish relevant indicators of the characteristics of supply and demand for investment resources in the construction of Ukraine. Thus, the proposed function of proposing investment resources in the field of construction is described by the following factors: household savings; financial result before taxation of business entities; working capital of economic entities; capital investments of business entities; capital investment from budgets; assets of insurance companies; assets of non-state pension funds; assets of credit unions; assets of banks; rate on long-term loans. In parallel, based on the analysis of the factors of influence on the supply and demand function on investment resources in construction, appropriate corrective indicators are identified. Thus, the indicators that should form the coefficient of correction of the function of the offer of investment resources in construction are defined: the index of investment attractiveness; index of financial freedom; index of freedom of investment; inflation index (consumer price index); official exchange rate of hryvnia to US dollar; the total tax burden on business.

The result of the scientific search was the development of a scientific and methodical approach to the formation of the function of the offer of investment resources in the construction of Ukraine in the form of multiplicative distributive-legal multi-factor nonlinear regression dependence, the effective index of which is formalized by adapting the metric of Minkowski. In contrast to existing approaches, the estimation of the function of the proposal for investment resources in construction is based on a combination of autocorrelation analysis and the consideration of nonlinear (exponential and polynomial) interconnections of input parameters. Further research will be aimed at quantifying the demand function for investment resources in construction and determining the points of intersection of demand functions and the supply of investment resources in the field of construction. In addition, it will be appropriate to pay attention to the modeling of optimal values of indicators of the characteristics of supply and demand functions, which will ensure the equilibrium of investment resources in construction.

\section{References}

1. Altonji, J.G. (1982). The intertemporal substitution model of labour market ${ }^{-}$uctuations: an empirical analysis, Review of Economic Studies, 49,78-82.

2. Bargain, O., Orsini K. and A. Peichl. (2012). Comparing Labor Supply Elasticities in Europe and the US: New Results, IZA Discussion Paper 6735, Institute for the Study of Labor, Bonn, Germany.

3. Blundell, R., C. Meghir and P. Neves (1993). Labour supply: an intertemporal substitution", Journal of Econometrics 59: 137-160.

4. Calabrese, G. (2000). Small -medium supplier-buyer relationships in the car industry: evidence from Italy. European Journal of Purchasing and Supply Management 6, 59-65.

5. Cambra-Fierro, J. J., Polo-Redondo, Y. (2008). Long-term orientation of the supply function in the SME context: reasons, determining factors and implications. International Small Business Journal, 26(5), 619-646

6. Choi, T. Y. and Krause, D. R. (2006). The supply base and its complexity: Implications for transaction costs, risks, responsiveness, and innovation. Journal of Operations Management, 24:637-652.

7. Ellram, L. M. and Choi, T. Y. (2000). Supply management for value enhancement. Technical report, National Association of Purchasing Management, Tempe, AZ.

8. Giunipero, L., Handfield, R. \& Eltantawy, R. (2006). Supply management's evolution: key skill sets for the supply manager of the future. International Journal of Operations \& Production Management 26(7), 822-844. 9. Hahn, C. K., Watts, C. A., and Kim, K. Y. (1989). Supplier development program at hyundai motor company. In Proceedings of the Purchasing Research Symposium, Tallahassee, Florida. 
10. Kaski, T. (2002). Product Structure Metrics as an Indicator of Demand-supply Chain Efficiency: Case Study in the Cellular Network Industry. PhD thesis, Helsinki University of Technology, Department of Industrial Engineering and Management.

11. Kim, S. W. (2006). Effects of supply management practices, integration and competition capability on performance, Supply Chain Management: An International Journal, 11(3), 241-248

12. Li, C. and Debo, L. (2009b). Strategic dynamic sourcing from competing suppliers with transferable capacity investment. Naval Research Logistics (forthcoming).

13. LI, G., Yang, H., Sun, L., Sohal, A. (2009). The impact of IT implementation on supply chain integration and performance. International Journal of Production Economics, 120, 125-138.

14. Li, Y. and Gupta, S. (2007). Strategic capacity investments and competition for supply contracts. SSRN eLibrary.

15. McMillan, J. (1990). Managing suppliers: Incentive systems in japanese and u.s. industry. California Management Review, 32(4).

16. Petersen, K. J., Handfield, R. B., Ragatz, G. L. (2005). Supplier integration into new product development: coordinating product, process and supply chain design, Journal of Operations Management, 23(3-4), 371-388. 17. Porter M. E. (1980) Competitive Strategy: Techniques for Analysing Industries and Competitors, Free Press..

18. Thompson A. A. and Strickland A. J. (1996), Strategic Management: concepts and cases, Irwin.

19. Wang, Y., Gillandy, W., and Tomlin, B. (2008). Mitigating supply risk: Dual sourcing or process improvement? working paper, W. P. Carey School of Business, Arizona State University

20. T. Kirichok (2013). Alhorytm rozv'yazannya bahatokryterial"noyi zadachi vyboru pokaznyka znoshuvannya banknot za do-pomohoyu funkciyi korysnosti [Algorithm for solving the multicriterial problem of choosing the indicator of wear of banknotes using the utility function]. Scientific news of NTUU "KPI", 1. 68-75.

21. Pro straxuvannya: Zakon Ukrayiny vid 07.03.1996 r. №1792- VIII. [On Insurance: Law of Ukraine dated March 7, 1996, No. 1792- VIII. ] Date of update 01.01.2017. Available at: http://zakon.rada.gov.ua

22. Pro nederzhavne pensijne zabezpechennya: Zakon Ukrayiny vid 03.10.2017 r. № 2148- VIII. Vidomosti Verxovnoyi Rady Ukrayiny [About non-state pension provision: Law of Ukraine dated October 3, 2017, No. 2148-VIII. Information from the Verkhovna Rada of Ukraine]. (2017). 47-48, 372.

23. Pro kredytni spilky: Zakon Ukrayiny vid 01.01.2016 r. № 835- VIII. Vidomosti Verxovnoyi Rady Ukrayiny. [On Credit Unions: Law of Ukraine dated January 1, 2016 No. 835- VIII. Information from the Verkhovna Rada of Ukraine]. (2013). 15, 101. 


\section{Appendix}

Table 1. Dynamics of input data for the evaluation of the supply of investment resources in the construction of Ukraine in 2000-2008

\begin{tabular}{|c|c|c|c|c|c|c|c|c|c|c|}
\hline \multirow{2}{*}{ 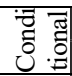 } & \multirow{2}{*}{ Indicator } & \multicolumn{9}{|c|}{ Year } \\
\hline & & 2000 & 2001 & 2002 & 2003 & 2004 & 2005 & 2006 & 2007 & 2008 \\
\hline S1 & Savings, million UAH. & 4203.0 & 6788.0 & 168015.0 & 16277.0 & 31077.0 & 45651.0 & 44203.0 & 47779.0 & 52011.0 \\
\hline S2 & $\begin{array}{l}\text { Financial result before taxa- } \\
\text { tion (profit / loss) mln. Grn. }\end{array}$ & 13933.0 & 26581.0 & 29156.0 & 34569.0 & 58421.0 & 64370.8 & 76253.4 & 110300.5 & 8954.2 \\
\hline S3 & Working capital, million & $223735.0^{*}$ & $264316.8^{*}$ & $312259.5^{*}$ & $368898.3^{*}$ & $435810.3^{*}$ & $514859.2 *$ & $608246.1^{*}$ & $718572.0^{*}$ & 848909.1 \\
\hline S4 & $\begin{array}{l}\text { Capital investments from en- } \\
\text { terprises, million }\end{array}$ & $17441.8^{*}$ & $20659.2^{*}$ & 24470.0 & 31306.0 & 46685.0 & 53424.0 & 72337.0 & 106520.0 & 132138.0 \\
\hline S5 & $\begin{array}{l}\text { Capital investments from } \\
\text { budgets of all levels, million }\end{array}$ & $2202.0^{*}$ & $2666.1^{*}$ & 3228.0 & 5665.0 & 11489.0 & 8992.0 & 12292.0 & 17782.0 & 21494.0 \\
\hline S6 & $\begin{array}{l}\text { Assets of insurers, UAH mil- } \\
\text { lion }\end{array}$ & $668.1^{*}$ & 794.3 & 1510.1 & 3160.1 & 6140.2 & 4321.3 & 6120.9 & 6765.5 & 8366.8 \\
\hline S7 & Assets NPF, million UAH & $0.9^{*}$ & $1.2^{*}$ & $1.7^{*}$ & $2.4^{*}$ & $3.3^{*}$ & 4.6 & 13.7 & 28.1 & 61.2 \\
\hline S8 & $\begin{array}{l}\text { Assets of credit unions, UAH } \\
\text { million }\end{array}$ & $598.0^{*}$ & $645.1 *$ & $695.9^{*}$ & 750.7 & 870.3 & 1939.5 & 3241.2 & 5261.0 & 6064.9 \\
\hline S9 & Assets of banks, mln. Grn .. & 10147.71 & 12927.09 & 17251.44 & 25514.20 & 34197.64 & 54441.67 & 86591.09 & 152573.55 & 235731.11 \\
\hline S10 & Rate on long-term loans, $\%$ & $16.8^{*}$ & $16.3^{*}$ & $15.7^{*}$ & $15.2^{*}$ & $14.7^{*}$ & 14.2 & 13.8 & 13.6 & 14.0 \\
\hline
\end{tabular}

Note: * predicted values calculated by the average growth rate.

Table 1. Dynamics of input data for the evaluation of the supply of investment resources in the construction of Ukraine in 2009-2017

\begin{tabular}{|c|c|c|c|c|c|c|c|c|c|c|}
\hline $\bar{\Xi}$ & & & & & & $\mathrm{Ye}_{\mathrm{C}}$ & & & & \\
\hline : & Indicator & 2009 & 2010 & 2011 & 2012 & 2013 & 2014 & 2015 & 2016 & 2017 \\
\hline S1 & Savings, UAH million & 80377.0 & 153358.0 & 123123.0 & 147280.0 & 116266.0 & 30780.0 & 31073.0 & 12591.0 & -16814.0 \\
\hline S2 & $\begin{array}{l}\text { Financial result before tax } \\
\text { (profit / loss), UAH million }\end{array}$ & -45011.3 & 58334.0 & 122210.0 & 101884.7 & 29283.2 & -523587.0 & -340126.6 & -22201.5 & 287848.5 \\
\hline S3 & Working capital, mln.UAH & 1155020.9 & 1305890.7 & 1586939.9 & 1748774.4 & 2046123.0 & 1940668.9 & 2223643.3 & 2879714.4 & 4495420.7 \\
\hline S4 & $\begin{array}{l}\text { Capital investment from en- } \\
\text { terprises, mln.UAH }\end{array}$ & 96019.0 & 111371.0 & 147569.6 & 171176.6 & 165786.7 & 154629.5 & 184351.3 & 248769.4 & 310061.7 \\
\hline S5 & $\begin{array}{l}\text { Capital investment from } \\
\text { budgets of all levels, mln }\end{array}$ & 10848.0 & 15954.1 & 25123.6 & 24844.0 & 12971.7 & 8656.9 & 21179.5 & 36081.2 & 56860.7 \\
\hline S6 & $\begin{array}{l}\text { Assets of insurers, UAH mil- } \\
\text { lion }\end{array}$ & 8291.9 & 9693.3 & 10024.8 & 17091.0 & 13269.9 & 14185.5 & 12746.6 & 12275.2 & 12629.6 \\
\hline S7 & Assets of NPF, UAH million & 85.8 & 114.4 & 138.7 & 166.0 & 209.0 & 246.9 & 198.0 & 213.9 & 246.6 \\
\hline S8 & $\begin{array}{l}\text { Assets of credit unions, UAH } \\
\text { million }\end{array}$ & 4218.0 & 3432.2 & 2386.5 & 2656.9 & 2598.8 & 2338.7 & 2064.3 & 2032.5 & 2169.8 \\
\hline S9 & Assets of banks, UAH mln. & $\begin{array}{c}222 \\
332.62 \\
\end{array}$ & 239803.20 & 268360.22 & 286918.39 & 325184.02 & 335164.55 & 318836.11 & 321582.20 & 326517.67 \\
\hline $\begin{array}{l}\text { S1 } \\
0\end{array}$ & Rate on long-term loans, $\%$ & 16.5 & 11.4 & 10.9 & 12.0 & 11.2 & 12.4 & 12.7 & 11.0 & 9.4 \\
\hline
\end{tabular}


Table 2. Dynamics of indicators of adjustment of supply for investment resources in construction

\begin{tabular}{|c|c|c|c|c|c|c|c|c|c|c|c|c|c|c|c|c|c|c|c|}
\hline \multirow{2}{*}{ № } & \multirow{2}{*}{ Indicator } & \multicolumn{18}{|c|}{ Year } \\
\hline & & 2000 & 2001 & 2002 & 2003 & 2004 & 2005 & 2006 & 2007 & 2008 & 2009 & 2010 & 2011 & 2012 & 2013 & 2014 & 2015 & 2016 & 2017 \\
\hline 1 & $\begin{array}{l}\text { Index of investment at- } \\
\text { tractiveness, units. }\end{array}$ & - & - & - & - & - & - & - & - & - & 2.5 & 3.2 & 2.9 & 2.2 & 2.1 & 2.7 & 2.6 & 2.9 & 3.1 \\
\hline 2 & $\begin{array}{l}\text { The index of financial } \\
\text { freedom, from }\end{array}$ & 30.0 & 30.0 & 30.0 & 50.0 & 50.0 & 50.0 & 50.0 & 50.0 & 50.0 & 40.0 & 30.0 & 30.0 & 30.0 & 30.0 & 30.0 & 30.0 & 30.0 & 30.0 \\
\hline 3 & $\begin{array}{l}\text { The index of freedom } \\
\text { of investment, from }\end{array}$ & 50.0 & 50.0 & 50.0 & 30.0 & 30.0 & 30.0 & 30.0 & 30.0 & 30.0 & 30.0 & 20.0 & 20.0 & 20.0 & 20.0 & 20.0 & 15.0 & 20.0 & 25.0 \\
\hline 4 & $\begin{array}{l}\text { Inflation index (con- } \\
\text { sumer price index), } \%\end{array}$ & 128.2 & 112.0 & 100.8 & 105.2 & 109.0 & 113.5 & 109.1 & 116.6 & 122.3 & 115.9 & 109.4 & 108.0 & 100.6 & 100.5 & 124.9 & 148.7 & 113.9 & 113.7 \\
\hline 5 & $\begin{array}{l}\text { Official exchange rate } \\
\text { of the UAH against the } \\
\text { US dollar, rubles. }\end{array}$ & 5.4 & 5.4 & 5.3 & 5.3 & 5.3 & 5.1 & 5.1 & 5.1 & 5.3 & 7.8 & 7.9 & 8.0 & 8.0 & 8.0 & 11.9 & 21.8 & 25.6 & 26.6 \\
\hline 6 & $\begin{array}{l}\text { Total tax burden on } \\
\text { business, } \%\end{array}$ & - & - & - & - & - & 57.3 & 57.0 & 56.6 & 57.2 & 57.2 & 55.5 & 57.1 & 55.4 & 54.4 & 52.7 & 52.2 & 52.3 & 37.8 \\
\hline
\end{tabular}

